\title{
TINDAK TUTUR EKSPRESIF DALAM NOVEL MY STUPID BOSS 5 KARYA CHAOS@WORK
}

\author{
Expressive Speech Act In Chaos@Work’s The Novel My Stupid Boss
}

\author{
Ai Kurniati \\ Balai Bahasa Kalimantan Tengah \\ Jalan Tingang, Km 3,5, Palangka Raya, Kalimantan Tengah 73112 \\ ai.kurniati@gmail.com
}

(Naskah Diterima Tanggal 4 Maret 2020_-Direvisi Tanggal 4 Mei 2020_-Disetujui Tanggal 21 Mei 2020)

\begin{abstract}
Abstrak
Novel My Stupid Boss 5 karya Chaos@Work ini menjadi novel yang paling ditunggu oleh penggemarnya setelah rilis novel My Stupid Boss $1-4$. Cerita berseri genre humor dalam novel ini merupakan kisah nyata dari penulisnya. Tulisan ini membahas tindak tutur dalam novel My Stupid Boss 5 karena hampir semua tuturan di dalam cerita novel ini mengandung ekspresi yang berbedabeda. Setiap ekspresi yang timbul merupakan strategi si penulis untuk menjadikan cerita tersebut memiliki daya humor. Tuturan-tuturan yang lucu dan menggemaskan dari tokoh dalam cerita tersebut, secara pragmatik dapat ditelaah dalam tindak tutur ilokusi, lebih khusus lagi tindak tutur ekspresif. Kajian ini bertujuan untuk mendeskripsikan tindak tutur ekspresif dalam novel My Stupid Boss 5. Metode yang digunakan adalah deskriptif-kualitatif sebagai prosedur pemecahan masalah dengan menggambarkan tindak tutur ekspresif dalam novel My Stupid Boss 5. Novel My Stupid Boss 5 karya Chaos@Work memiliki kecenderungan memiliki tindak tutur ilokusi ekspresif dengan lima (5) indikator: (a) tindak tutur ekspresif mengkritik, (b) tindak tutur ekspresif mengeluh, (c) tindak tutur ekpresif menyalahkan, (d) tindak tutur ekspresif memuji, dan (e) tindak tutur ekspresif menyanjung.
\end{abstract}

Kata kunci: tindak tutur ekspresif, novel My Stupid Boss 5

\begin{abstract}
The novel My Stupid Boss 5 by Chaos @ Work became the most awaited novel by fans after the release of the novel My Stupid Boss 1-4. The series of humorous stories in this novel are true stories from the author. This paper discusses the speech acts in the novel My Stupid Boss 5 because almost all the utterances in the story of this novel contain different expressions. Every expression that arises is the author's strategy to make the story have a sense of humour. The funny and adorable utterances of the characters in the story, pragmatically, can be examined in illocutionary acts, more specifically expressive speech acts. This study aims to describe expressive speech acts in the novel My Stupid Boss 5. The method used is descriptive-qualitative as a problem solving procedure by describing expressive speech acts in the novel My Stupid Boss 5. My Stupid Boss 5 novel byChaos @ Work has a tendency to have expressive illocutionary acts with five (5) indicators: (a) expressive speech acts criticizing, (b) expressive speech acts of complaining, (c) expressive speech acts of blamming, (d) expressive speech acts praising, and (e) expressive speech acts flatterin.
\end{abstract}

Keywords: expressive speech act, the novel My Stupid Boss 5

\section{PENDAHULUAN}

Cerita dalam novel My Stupid Boss karya Chaos@Work ini sempat menjadi topik utama dalam percaturan dunia humor di Indonesia. Cerita berseri dalam novel ini merupakan kisah nyata dari penulisnya. Cerita ini menggambarkan seputar dunia kerja seorang sekretaris bersama atasannya dengan segala kompleksitasnya. Novel ini sangat menarik, selain isi cerita yang kocak, gambaran tentang tempat, suasana, dan 
bahasa yang ringan memberikan nuansa yang lucu dari keseluruhan isi novel.

Gaya dan sikap seenaknya seorang atasan terhadap karyawan bahkan orang lain yang tidak dikenal menjadi daya pikat dalam novel ini. Terlebih cara berkomunikasi tokoh sentral dalam novel ini kurang memerhatikan perasaan orang lain, sehingga akan ditemukan banyak sekali ekspresi dalam setiap tuturannya. Hampir semua bab membahas tentang pengalaman-pengalaman konyol seputar atasan, karyawan, dan perusahaan. Cerita ini telah rampung sampai dengan serial kelima. Menjadi buku yang banyak diminati dan dicari para penggemarnya. Cerita ini bahkan telah dibuat visualisasi/difilmkan dengan judul yang sama dengan novelnya. Film tersebut disutradarai dan dibintangi oleh para sineas papan atas negeri ini, tentu saja berhasil memikat penonton yang sangat banyak.

Kisah-kisah lucu dalam novel My Stupid Boss karya Chaos@Work ini bermula saat penulis novel ini (tokoh utama) mengikuti suaminya dan tinggal di Malaysia. Dia bekerja di perusahaan dengan atasannya adalah orang Indonesia juga. Oleh karena penulis novel ini (tokoh utama) termasuk tenaga kerja asing, dia bekerja dengan sistem kontrak untuk beberapa tahun. Dalam sistem kontrak tersebut, jika salah satu pihak hendak memutuskan kontrak sebelum waktunya, pihak tersebut harus membayar sisa bulan kerja sebagai ganti rugi kepada pihak yang lainnya. Jika Si Penulis novel ini (tokoh utama) hendak keluar, dia harus membayar kepada atasannya. Begitu pula sebaliknya, jika atasan akan memecatnya, atasannyalah yang harus membayar ganti rugi kepadanya. Jadi, antara atasan dan si penulis novel ini yang sebagai tokoh utamanya yang keduanya berada dalam posisi yang sama. Oleh karena itu, hampir setiap hari terjadi perseteruan yang kocak di antara keduanya.

Hampir semua tuturan di dalam cerita novel ini mengandung ekspresi yang berbeda-beda. Setiap ekspresi yang timbul merupakan strategi si penulis untuk menjadikan cerita tersebut memiliki daya humor. Tuturan-tuturan yang lucu dan menggemaskan dari beberapa tokoh dalam cerita tersebut, secara pragmatik dapat ditelaah dalam tindak tutur ilokusi, lebih khusus lagi tindak tutur ekspresif.

Kajian mengenai tindak tutur ekspresif sudah banyak dilakukan, antara lain oleh (Defina, 2018) yang mengkaji menganalisis jenis tindak tutur ilokusioner ekspresif yang dihasilkan oleh anak-anak untuk berkomunikasi saat bermain bola di lapangan.; (Chamalah, 2016) mengkaji membahas tentang tindak tutur ekspresif yang tertulis pada bak truk sebagai alternatif materi ajar Pragmatik.; (Riswanti, 2014) membahas tindak tutur direktif dan ekspresif dalam novel Kembang Saka Persi karya Soebagio I. N. (Murti, Nisai Muslihah, \& Permata Sari, 2018) yang mengupas tindak tutur ekspresif dalam film Kehormatan di Balik Kerudung, juga (Susmiati, Tutik; Andianto, Mujiman Rus; Husniah, 2013) menelaah tindak tutur ekspresif guru terhadap siswa dalam pembelajaran Bahasa Indonesia.

Masalah pragmatik, khususnya tindak tutur ilokusi sudah banyak dibahas oleh para peneliti bahasa, begitu pun tindak tutur ekspresif. Yang berbeda dari tulisan ini adalah mengungkap tindak tutur ekspresif dalam novel My Stupid Boss 5( Chaos@Work, 2016 ).

Menurut (Austin, 1962) tindak tutur (speech acts) ialah pengucapan suatu kalimat saat si penutur tidak semata-mata menanyakan atau meminta jawaban tertentu, tetapi ia juga menindakkan sesuatu. Tindak tutur ilokusi adalah sebuah tuturan selain berfungsi untuk mengatakan atau menginformasikan sesuatu, dapat juga dipergunakan untuk melakukan sesuatu.

Penulis tergerak untuk membahas tuturan dalam cerita novel My Stupid Boss 5 karya Chaos@Work dengan alasan bahwa tuturan dalam novel My Stupid Boss 5 karya Chaos@Work tersebut sangat komunikatif, 
bahkan interaktif dan ekspresif. Bahasan akan difokuskan pada kajian pragmatik, yakni tindak tutur ilokusi, khususnya tindak tutur ekspresif. Penulis mengambil data tuturan dalam novel My Stupid Boss 5 karya Chaos@Work.

Berdasarkan uraian di atas, tulisan yang bertujuan untuk mendeskripsikan tindak tutur (speech act) ilokusi yang terdapat dalam novel My Stupid Boss 5 karya Chaos@Work, khususnya tindak tutur ekspresif. Dengan demikian, rumusan masalah tulisan ini adalah tindak tutur (speech act) ekspresif apa saja yang terdapat dalam novel My Stupid Boss 5 karya Chaos@Work?

Diketahui bahwa satuan terkecil dalam komunikasi linguistik bukanlah simbol atau kata atau kalimat melainkan produk dari suatu kalimat yang berupa tindak tutur atau tindak ujar (speech act) (Searle, 1971) dan (Blum-Kulka, 1989). Peristiwa tutur (speech event) merupakan terjadinya atau berlangsungnya interaksi linguistik dalam satu bentuk ujaran atau lebih yang melibatkan dua pihak, yaitu penutur dan mitra tutur, dengan satu pokok tuturan di dalam suatu waktu, tempat, dan situasi tertentu.

Dapat dikatakan bahwa peristiwa tutur merupakan rangkaian dari sejumlah tindak tutur yang terorganisasi untuk mencapai suatu tujuan. Peristiwa tutur merupakan gejala individual, bersifat psikologis, dan keberlangsungannya ditentukan oleh kemampuan bahasa si penutur dalam menghadapi situasi tertentu. Jika dalam peristiwa tutur lebih dilihat pada tujuan, dalam tindak tutur lebih ditekankan pada makna dan arti tindakan dalam tuturannya. Oleh karena itu, tindak tutur dan peristiwa tutur merupakan dua gejala yang terdapat pada satu proses, yaitu proses komunikasi.

Sesuai dengan pandangan tindak tutur dan peristiwa tutur, tuturan dalam novel $M y$ Stupid Boss 5 karya Chaos@Work dapat dipandang sebagai bentuk komunikasi linguistik karena mengandung tindak tuturtindak tutur.

Menurut pandangan (Austin, 1962), semua tuturan adalah performatif. Maksudnya semua tuturan merupakan sebuah bentuk tindakan dan tidak sekadar mengatakan sesuatu. Austin juga membedakan antara tindak lokusi dan tindak ilokusi, selanjutnya Austin melengkapi kategori-kategori ini dengan menambah kategori perlokusi. Tindak tutur lokusi adalah tindak tutur yang menyatakan sesuatu sebagaimana adanya atau the act of saying something atau dengan kata lain makna leksikal dan makna sintaksis kalimat bersesuaian. Fokus lokusi adalah makna tuturan yang diucapkan, bukan mempermasalahkan maksud atau fungsi tuturan itu.

Tindak tutur ilokusi adalah tindak tutur yang biasanya diindentifikasikan dengan kalimat performatif yang eksplisit. Dengan kata lain, ilokusi adalah tindak tutur yang mengandung maksud dan fungsi atau daya tuturan atau the act of doing something, sedangkan tindak tutur perlokusi adalah tindak tutur yang dilakukan untuk mendapatkan efek psikologis tertentu. Tindak tutur ini sering disebut the act of affecting someone.

Searle (1975) mengklasifikasi tindak tutur ilokusi menjadi lima kategori yaitu:

1. Representatif/asertif, yaitu tuturan yang mengikat penuturnya akan kebenaran atas apa yang diujarkan. Tindak tutur jenis ini disebut juga dengan tindak tutur asertif. Yang termasuk tindak tutur jenis ini adalah tuturan menyatakan, menuntut, mengakui, menunjukkan, melaporkan, memberikan kesaksian, menyebutkan, dan berspekulasi.

2. Direktif/imposif, yaitu tindak tutur yang dimaksudkan penuturnya agar si pendengar melakukan tindakan yang disebutkan di dalam tuturan itu. tindak tutur direktif disebut juga dengan tindak tutur imposif. Yang termasuk ke dalam tindak tutur jenis 
ini antara lain meminta tuturan, mengajak, memaksa, menyarankan, mendesak, menyuruh, menagih, memerintah, memohon, menatang, dan memberi aba-aba. Indikator dari tuturan direktif adalah adanya tindakan yang dilakukan oleh mitra tutur setelah mendengar tuturan tersebut.

3. Ekspresif/evaluatif adalah tindak tutur yang dimaksudkan penuturnya agar tuturannya diartikan sebagai evaluasi tentang hal yang disebutkan dalam tuturan itu. Yang termasuk dalam tindak tutur jenis ini adalah tuturan mengucapkan terima kasih, mengeluh, mengucapkan selamat, menyanjung, memuji, menyalahkan, dan mengkritik.

4. Komisif adalah tindak tutur yang mengikat penuturnya untuk melaksanakan segala hal yang disebutkan dalam ujarannya, misalnya bersumpah, berjanji, mengancam, menyatakan kesanggupan, dan berkaul.

5. Deklarasi/isbati yaitu tindak tutur yang dimaksudkan penuturnya untuk menciptakan hal (status, keadaan, dsb) yang baru. Tindak tutur ini disebut juga dengan istilah isbati. Yang termasuk ke dalam jenis tuturan ini adalah tuturan dengan maksud mengesankan, memutuskan, membatalkan, melarang, mengabulkan, mengizinkan, menggolongkan, mengangkat, mengampuni, dan memaafkan.

Tindak tutur juga dibedakan menjadi dua, yaitu tindak tutur langsung dan tindak tutur tidak langsung. Penggunaan tuturan secara konvensional menandai kelangsungan suatu tindak tutur langsung. Tuturan deklaratif, tuturan interogatif, dan tuturan imperatif secara konvensional dituturkan untuk menyatakan suatu informasi, menanyakan sesuatu, dan memerintahkan mitra tutur melakukan sesuatu. Kesesuaian antara modus dan fungsinya secara konvensional inilah yang merupakan tindak tutur langsung. Sebaliknya, jika tuturan deklaratif digunakan untuk bertanya atau memerintah, atau tuturan yang bermodus lain yang digunakan secara tidak konvensional, tuturan itu merupakan tindak tutur tidak langsung. Derajat kelangsungan tindak tutur dapat diukur melalui kejelasan pragmatiknya.

Rustono (1999) mengungkapkan tindak tutur ekspresif adalah tindak tutur yang dihasilkan penutur dengan tujuan agar tuturannya diartikan sebagai evaluasi tentang hal yang disebutkan di dalam tuturan itu. Rustono juga membagi tindak tutur ekspresif ini menjadi tujuh. Ketujuh tindak tutur itu adalah 1) tindak tutur ekspresif dengan indikator mengkritik, 2) tindak tutur ekspresif dengan indikator mengeluh, 3) tindak tutur ekspresif dengan indikator menyalahkan, 4) tindak tutur ekspresif dengan indikator memuji, 5) tindak tutur ekspresif dengan indikator mengucapkan terima kasih, 6) tindak tutur ekspresif dengan indikator mengucapkan selamat, dan 7) tindak tutur ekspresif dengan indikator menyanjung.

Austin (1962) membagi tindak tutur ekspresif ini menjadi enam. Keenam tindak tutur ekspresif itu adalah 1) berterima kasih (thanking), 2) memberi selamat (congratulating), 3) meminta maaf (pardoning), 4) menyalahkan (blaming), 5) memuji (praising), dan 6) belasungkawa (condoling). Sementara Searle (1976: 12) menyatakan bahwa tindak tutur ekspresif digunakan untuk mengekspresikan keadaan psikologis dalam kondisi ketulusan atau perasaan sebenarnya dalam konten proposisional. Tindak tutur yang termasuk ke dalam tindak tutur ekspresif, di antaranya 1) menyambut, 2) memuji, dan 3) menyalahkan.

Adapun (Yule, 1996) menyatakan bahwa tindak tutur yang tergolong ekspresif adalah tindak tutur berupa pernyataan yang 
bermakna kesenangan, rasa sakit, suka, tidak suka, suka cita, atau sedih.

Penelitian ini disebut sebagai penelitian sosiopragmatik, karena yang dikaji adalah penggunaan bahasa (language use, bukan language usage) di dalam sebuah masyarakat budaya di dalam situasi sosial tertentu. Seperti yang dikatakan Leech (1983:10-11), sosiopragmatik itu adalah salah satu dari dua sisi pragmatik, yang sisi lainnya adalah pragmalinguistik. Yang pertama itu berhubungan dengan sosiologi dan yang kedua (pragmalinguistik) berhubungan dengan tata bahasa (grammar), dengan catatan bahwa pengertian grammar di sini adalah seperti yang dipakai di dalam paradigma linguistik generatif transformasional (yaitu meliputi fonologi dan semantik juga), bukan seperti yang dipakai di dalam paradigma linguistik struktural (yaitu terbatas pada morfologi dan sintaksis saja).

Istilah "pragmatik" sendiri, sebagai bidang kajian di dalam ilmu linguistik, diberi batasan yang berbedabeda oleh pakar-pakar linguistik. Namun, dari batasanbatasan yang berbeda-beda itu dapat ditelusuri adanya dua tradisi pragmatik, yaitu tradisi Anglo-Amerika dan tradisi kontinental (Levinson, 1983:5). Yang pertama itu lebih terbatas dan lebih erat kaitannya dengan apa yang secara tradisional menjadi bidang kajian linguistik seperti struktur kalimat dan tata bahasa. Yang kontinental itu lebih luas dan meliputi analisis wacana, etnografi komunikasi, beberapa aspek psikolinguistik dan bahkan kajian tentang kata sapaan (Fasold, 1984:119). Bagaimana pun, salah satu batasan pragmatik yang berterima oleh para pengikut kedua tradisi itu adalah bahwa bidang ini adalah bidang di dalam linguistik yang mengkaji maksud ujaran, bukan makna kalimat yang diujarkan itu. Makna kalimat dikaji di dalam semantik, sedangkan maksud atau daya (force) ujaran dikaji di dalam pragmatik. Sebagai contoh, bahwa kalimat Saudara dapat berbahasa Belanda? bermakna penanya ingin tahu apakah yang ditanya itu mempunyai kemampuan berbahasa Belanda, ini adalah bidang semantik. Bahwa ujaran "Saudara dapat berbahasa Belanda ?" dimaksudkan oleh si penanya sebagai permintaan untuk menerjemahkan sebuah kata bahasa Belanda, misalnya, ini adalah bidang pragmatik.

Pragmatik antara lain memang mempelajari maksud ujaran atau daya (force) ujaran. Kita juga dapat mengatakan bahwa pragmatik juga mempelajari fungsi ujaran: untuk apa suatu ujaran dibuat atau dilakukan. Atas dasar ini dapat kita katakan bahwa pragmatik itu termasuk ke dalam fungsionalisme di dalam linguistik. Salah satu satuan analisisnya bukanlah kalimat (karena kalimat adalab satuan tata bahasa), melainkan tindak ujaran atau tindak tutur (speech act). SebagaiMana tindak ujaran bukan kalimat, is juga tidak persis sama dengan ujaran. Dengan satu ujaran "Saga haus", misalnya, sebenarnya kita melakukan dua tindak ujaran, yaitu memberitahu dan meminta.

Austin (1969) membedakan tiga jenis tindakan yang berkaitan dengan ujaran. Ketiganya adalah tindak lokusioner, tindak ilokusioner dan tindak perlokusioner atau, singkatnya, lokusi, ilokusi dan perlokusi. Yang pertama itu semata-mata adalah tindak berbicara, yaitu tindak mengucapkan sesuatu dengan makna kata dan makna kalimat sesuai dengan makna kata itu (di dalam kamus) dan makna sintaktis kalimat itu menurut kaidah sintaktisnya. Di dalam hal ini kita tidak memasalahkan maksud atau fungsi ujaran yang merupakan perpanjangan atau perluasan dari makna harfiah itu. Jadi, kalau dengan mengujarkan "Saya haus" seseorang mengartikan "saya" sebagai orang pertama tunggal, dan "haus" sebagai mengacu ke "tenggorokan kering dan perlu dibasahi", tanpa bermaksud untuk minta minum, misalnya, orang ini dikatakan melakukan lokusi. Mungkin saja orang itu sekadar mengujarkan sebuah baris dari sebuah puisi atau nyanyian. Sekadar tambahan, jika seandainya orang itu mengatakan "Haya Gauss", misalnya, is tidak dapat dikatakan melakukan lokusi (setidak-tidaknya di dalam bahasa Indonesia) karena yang is katakan itu tidak bermakna.

Yang kedua, tindak ilokusioner atau ilokusi, adalah tindak melakukan sesuatu dalam mengatakan sesuatu. Di sini kita berbicara tentang maksud, fungsi atau daya ujaran yang bersangkutan, dan bertanya "Untuk apa ujaran itu dilakukan ?" Jadi, "Saya haus" yang 
dimaksudkan untuk minta minum adalah sebuah tindak ilokusioner atau ilokusi.

Yang ketiga, tindak perlokusioner atau perlokusi, menurut Austin mengacu ke efek yang dihasilkan penutur dengan mengatakan sesuatu. Di sinilah ketidakjelasan rumusan Austin itu. Lokusi dan ilokusi dikatakan sebagai tindak (act), sedangkan perlokusi dikatakan sebagai efek. Jika dikatakan bahwa perlokusi adalah tindak melakukan sesuatu dengan mengatakan sesuatu (Leech, 1983:199), ini pun agak rancu dengan batasan ilokusi di atas karena bedanya hanyalah terletak pada dalam mengatakan sesuatu dan dengan mengatakan sesuatu. Sekadar untuk membedakan kedua jenis tindak tutur ini, ada kata-kata kerja yang menunjukkan bahwa tindak tuturnya adalah ilokusi (misalnya melaporkan, mengumumkan, bertanya, menyarankan, berterima kasih dan sebagainya) dan ada kata-kata kerja yang menunjukkan bahwa tindak tuturnya adalah perlokusi (misalnya membujuk, menipu, membuat jengkel, menakut- nakuti dan sebagainya) (Lihat Leech, 1983:203). Masalahnya adalah bahwa ada kata kerja yang tidak menunjukkan dengan jelas apakah tindak ujarannya: ilokusi ataukah perlokusi. Ujaran "Saya haus" di atas, misalnya, dapat juga berfungsi sebagai perlokusi jika diucapkan oleh penculik anak, misalnya, untuk menakut-nakuti anak kecil yang diculik setelah sebelumnya diberitahu bahwa jika dan bila haus, si penculik selalu minum darah. Satu petunjuk bahwa tindak tutur itu adalah perlokusi ialah adanya efek dari tindak tutur itu, yaitu bahwa si anak menjadi takut. Barangkali jika dikatakan bahwa perlokusi adalah tindak tutur yang dilakukan si penutur untuk menimbulkan efek (di benak interlokutor) dengan mengatakan sesuatu, pengertian perlokusi lebih mudah dibedakan dari pengertian ilokusi.

Yang penting disebutkan sehubungan dengan pengertian tindak ujaran atau tindak tutur itu adalah bahwa ujaran (entah berapa jumlahnya) dapat dikategorikan, seperti yang diutarakan oleh Searle (1975), menjadi lima jenis

(1)representatif (kadang-kadang disebut asertif), yaitu tindak tutur yang mengikat penuturnya kepada kebenaran atas apa yang dikatakannya (misalnya : menyatakan, melaporkan, menunjukkan, menyebutkan);

(2) direktif, yaitu tindak tutur yang dilakukan penuturnya dengan maksud agar si pendengar melakukan tindakan yang disebutkan di dalam ujaran itu (misalnya menyuruh, memohon, menuntut, menyarankan, menantang);

(3)ekspresif, yaitu tindak tutur yang dilakukan dengan maksud agar ujarannya diartikan sebagai evaluasi tentang hal yang disebutkan di dalam ujaran itu (misalnya : memuji, mengucapkan terima kasih, mengritik, mengeluh);

(4)komisif, yaitu tindak tutur yang mengikat penuturnya untuk melaksanakan apa yang disebutkan di dalam ujarannya (misalnya : berjanji, bersumpah, mengancam); dan

(5)deklarasi (bukan deklaratif), yaitu tindak tutur yang dilakukan si penutur dengan maksud untuk menciptakan hal (status, keadaan, dan sebagainya) yang baru (misalnya memutuskan, membatalkan, melarang, mengizinkan, memberi maaf).

Dari beberapa konsep tindak tutur ekspresif tersebut dapat disimpulkan bahwa tindak tutur ekspresif adalah tindak tutur yang dihasilkan oleh kondisi psikologi seorang penutur berdasarkan kondisi di lingkungannya. Keadaan psikologi itu dapat berupa ekspresi kesenangan/kebahagiaan (seperti tuturan terima kasih, memuji), kekecewaan (seperti tuturan menyalahkan), kesakitan (seperti tuturan mengeluh), dan kesedihan (seperti tuturan belasungkawa). Kemudian, dari konsep-konsep yang dikemukakan pakar tersebut juga dapat disimpulkan juga bahwa yang termasuk tindak tutur ekspresif adalah 1) berterima kasih, 2) memberi selamat, 3) meminta maaf, 4) menyalahkan, 5) memuji, 6) belasungkawa, 7) menyambut, 8) mengkritik, 9) mengeluh, dan 10) menyanjung. 


\section{METODE}

Metode dan teknik penelitian ini terbagi atas tiga tahap sesuai dengan yang disarankan oleh Sudaryanto (1993: 5-8), yaitu 1) metode dan teknik penyediaan data, 2) metode dan teknik penganalisisan data, dan 3) metode dan teknik penyajian data. Penyediaan data dilakukan dengan pengamatan tuturan dalam novel My Stupid Boss 5 karya Chaos@Work yang telah ditetapkan dengan menggunakan teknik pengartuan data dan mendeskripsikan segala hal yang berhubungan dengan tindak tutur.

Kemudian tahap selanjutnya, menyeleksi data yang sudah terkumpul. Kegiatan ini bertujuan untuk menajamkan, menggolongkan, mengarahkan data yang akan dipakai, membuang data yang tidak perlu, serta mengorganisasi data hingga simpulan-simpulan finalnya dapat ditarik dan diverifikasi. Dalam proses ini, data dipilih sesuai dengan rumusan masalah dan tujuan penelitian. Selanjutnya memilah data yang sudah terkumpul. Kegiatan ini berlangsung hingga didapatkan data-data yang sesuai, kemudian berikutnya tahap penganalisisan.

Kegiatan dilanjutkan dengan penyajian hasil analisis. Pada tahap ini adalah kegiatan-kegiatan analisis dalam bentuk mengorganisasi dan menyusun data menjadi informasi bermakna ke arah simpulan penelitian. Penyajian hasil analisis dapat dilakukan dengan dua cara, yaitu formal dan informal (Sudaryanto, 1993: 145). Metode penyajian formal berupa perumusan kaidah-kaidah tabel-tabel dan diagram, sedangkan metode penyajian informal berupa eksplanasi biasa, yaitu perumusan dengan menggunakan kata-kata biasa. Dalam penelitian ini, penyajian hasil analisis hanya menggunakan metode penyajian informal berupa penjelasan biasa, yaitu perumusan dengan menggunakan kata-kata biasa.

\section{PEMBAHASAN}

Tindak Tutur Ekspresif dalam Novel $M y$ Stupid Boss 5 Karya Chaos@Work

Tindak tutur ekspresif dilakukan dengan maksud agar tuturan diartikan sebagai evaluasi tentang hal yang disebutkan di dalam tuturannya itu. Berdasarkan analisis data yang dilakukan, pada umumnya tindak tutur dalam tuturan novel My Stupid Boss 5 karya@Chaos@Work memiliki kecenderungan bertindak tutur ilokusi ekspresif dengan lima (5) indikator: (a) tindak tutur ekspresif mengkritik, (b) tindak tutur ekspresif mengeluh, (c) tindak tutur ekpresif menyalahkan, (d) tindak tutur ekspresif memuji, dan (e) tindak tutur ekspresif menyanjung.

\section{Tindak Tutur Ekspresif Mengkritik}

Mengkritik identik dengan mengecam atau menanggapi sesuatu hal. Tindak tutur ekspresif dengan indikator mengkritik ditandai dengan adanya tuturan dari penutur yang berupa kecaman atau tanggapan yang disertai dengan uraian dan pertimbangan baik atau buruk terhadap suatu karya, pendapat, tindakan dan sebagainya yang ditujukan kepada mitra tuturnya. Contoh berikut mengandung tindak tutur ekspresif dengan indikator mengkritik.
(1) "Ya, bagaimanalah yang sepatutnya. Tunjukin perhatian sama owner perusahaan yang lagi sakit. (MSB5: 23)

Contoh data (1) memiliki konteks kritikan yang ditujukan tokoh atasan (bossman) kepada bawahannya (karyawannya) agar bawahannya memiliki perhatian terhadap karyawannya. Tuturan pada contoh di atas diungkapkan tokoh Bossman yang sedang sakit kepada karyawannya yang seolah-olah tidak memperhatikannya. Tuturan tersebut mengandung unsur kritikan karena di dalamnya terdapat kecaman seorang tokoh terhadap mitra tuturnya. Contoh di bawah ini juga mengandung tindak tutur ekspresif dengan indikator mengkritik. 
(2) Gue : Ask me! Ask me!

Bossman : Diamlah kamu!

Konteks contoh data (2) adalah tokoh Bossman (atasan) yang mengkritik tokoh Gue (bawahan) agar diam (tidak bicara) karena pada tuturan sebelumnya tokoh Gue yang menuturkan sesuatu yang sangat mengganggu tokoh Bossman. Tuturan tokoh Bossman pada contoh data (2) di atas merupakan contoh tindak tutur ekspresif dengan indikator mengkritik. Tuturan tersebut dimaksudkan agar mitra tutur mendengar dan mengikuti hal yang disampaikan penutur. Pada dasarnya kritikan berisi kecaman. Kecaman pada contoh data (2) tersebut lebih mengandung teguran yang keras agar mitra tutur tidak bicara (diam). Tindak tutur ekspresif lainnya dengan indikator mengkritik dapat dilihat berikut ini.

(3) Bossman : Kamu jelek banget kalo abis bangun tidur!

(MSB5:131)

Konteks contoh data (3) adalah ketika tokoh Bossman (atasan) mengetuk pintu kamar dan membangunkan tokoh Gue (bawahan) di sebuah hotel. Kemudian keluarlah tuturan mengkritik dari tokoh Bossman. Tuturan tokoh Bossman pada contoh data (3) di atas merupakan tindak tutur ekspresif dengan indikator mengkritik. Tuturan pada kalimat "Kamu jelek banget kalo abis bangun tidur!" pada contoh data tersebut jelas sekali merupakan kritikan/kecaman atau celaan terhadap mitra tutur. Perhatikan pula contoh tindak tutur ekspresif lainnya dengan indikator mengkritik berikut ini.

(4) Bossman : Itu orang kenapa teriakteriak?

Gue : Gak tau

Bossman : Coba tanya!

Gue : Kita ini di Vietnam.., bukan di Glodok.

(MSB5:139)

Konteks contoh data (4) adalah bertempat di Vietnam, tokoh Bossman yang kesal dan terus menanyakan sesuatu yang tidak diketahui mitra tuturnya (tokoh Gue) lalu menyuruh tokoh Gue untuk bertanya. Tokoh Gue pun akhirnya melayangkan kritikan kepada tokoh Bossman. Kritikan tersebut terdapat pada kalimat "Kita ini di Vietnam.., bukan di Glodok" merupakan indikator tindak tutur ekspresif mengkritik tokoh Gue kepada tokoh Bossman. Terjadinya tindak tutur ekspresif mengkritik pada tuturan tersebut karena konteks kalimat tersebut berada di Vietnam, bukan di Glodok (Indonesia). Jadi, tokoh Bossman tidak perlu mempertanyakan sesuatu hal yang samasama tidak diketahui dan dipahami keduanya. Tindak tutur ekspresif lainnya dengan indikator mengkritik terdapat pada contoh data di bawah ini.

(5) "Biasa aja mukanya! Gak usah jutek gitu!" (MSB5:181)

Adapun konteks contoh data (5) kritikan yang meluncur dari tuturan tokoh Bossman kepada bawahannya. Kritikan muncul setelah tokoh Bossman melihat wajah bawahannya yang bermuka masam. Bawahannya bermuka masam karena sebelumnya tokoh Bossman mencela dan menyalahkan bawahannya. Ekspresi mengkritik hadir pada tuturan tersebut. Lihat kalimat "Biasa aja mukanya! Gak usah jutek gitu!". Kritikan tokoh Bossman tersebut mengalir begitu saja kepada bawahannya setelah sebelumnya mencela bawahannya. Itu yang membuat cerita ini semakin pragmatis dan memiliki kekuatan humor yang tinggi.

\section{Tindak Tutur Ekspresif Mengeluh}

Selain tindak tutur mengkritik, dalam novel My Stupid Boss 5 ini juga ditemukan tindak tutur ekspresif mengeluh. Tindak tutur ekspresif dengan indikator mengeluh ditandai dengan tuturan yang berisi keluhan penutur kepada mitra tutur atau pihak yang dituju. Contoh di bawah ini mengandung tindak tutur ekspresif dengan indikator mengeluh. 
(6) "Aduh, Bu...(megang pinggang) Pinggang saya sakit."

(MSB5:21)

Konteks contoh data (6) adalah tokoh Bossman (atasan) yang mengeluh karena pinggangnya sakit. Tuturan tokoh Bossman pada contoh data (6) di atas merupakan contoh tindak tutur ekspresif dengan indikator mengeluh. Tuturan tersebut mengandung keluhan karena berisi ucapan yang disebabkan kesusahan (kesakitan) pada kalimat "Aduh, Bu...(megang pinggang) Pinggang saya sakit." Tindak tutur ekspresif lainnya dengan indikator mengeluh dapat dilihat pada contoh data berikut ini.

(7) "Bapak...baik-baik aja?"

"Iya... saya cuman anu.. takut..."

"Takut apa?"

"Takut jarum."

(MSB5:38)

Konteks contoh data (7) adalah tokoh Bossman (atasan) yang mengeluh karena takut jarum suntik, padahal saat itu dia sendiri menawarkan untuk donor darah. Tampak dari tuturan tokoh Bossman di atas merupakan contoh tindak tutur ekspresif dengan indikator mengeluh. Tindak tutur ekspresif indikator mengeluh tersebut terdapat pada kalimat "Iya... saya cuman anu.. takut..." dan kalimat "Takut jarum." Data berikut juga mengandung tindak tutur ekspresif dengan indikator mengeluh.

(8) "Serem amat nih cuacanya. Pilotnya bisa diganti enggak ya?

(MSB5:41)

Konteks contoh data (8) adalah tokoh Bossman (atasan) yang mengeluh karena situasi penerbangan yang sedang dijalaninya begitu menyeramkan. Terlihat tokoh Bossman pada tuturan di atas mengeluhkan cuaca yang buruk dan penerbangan yang membuatnya merasa seram/takut. Tuturan tersebut dapat dikatakan sebagai tindak tutur ekspresif dengan indikator mengeluh. Perhatikan contoh data berikut juga termasuk tindak tutur ekspresif dengan indikator mengeluh.

(9) "Saya takut!"

"Apalagi saya! Saya kan perempuan!

Makhluk lemah!"

"Saya sudah tua!"

(MSB5:76)

Konteks contoh data (9) percakapan antara Bossman dan tokoh Gue, bawahannya terjadi di ruang mayat, terdapat tiga ungkapan mengeluh, pertama dari tokoh Bossman, kedua dari tokoh Gue, dan yang ketiga dari tokoh Bossman. Tindak tutur ekspresif dengan indikator mengeluh tampak sekali dengan adanya tiga keluhan di atas. Kalimat pertama "Saya takut!" adalah ekspresi mengeluh ketakutan seorang tokoh Bossman, kalimat kedua "Apalagi saya! Saya kan perempuan! Makhluk lemah!” merupakan ekspresi mengeluh karena penutur seorang perempuan yang serting dicap sebagai makhluk yang lemah, dan kalimat ketiga "Saya sudah tua!" mengandung ekspresi mengeluh dari tokoh Bossman yang sudah berusia lebih tua daripada mitra tuturnya. Contoh lainnya dari tindak tutur ekspresif dengan indikator mengeluh.

(10) "Aduh! Aduh! Saya ketimpa gajah! Aduuhh!!"

(MSB5:172)

Konteks contoh data (10) adalah tokoh Gue (bawahan) yang jatuh menimpa tokoh Bossman (atasan), kemudian muncul ekspresi mengeluh tokoh Bossman. Tuturan tokoh Bossman terdapat pada kalimat "Aduh! Aduh! Saya ketimpa gajah! Aduuhh!!" tersebut merupakan contoh tindak tutur ekspresif dengan indikator mengeluh. Tindak tutur ekspresif yang dilakukan oleh tokoh Bossman tampak sekali mengandung keluhan karena diakibatkan rasa sakit yang dideritanya, meskipun yang sebenarnya bukan tertimpa gajah seperti yang dikatakan penutur, melainkan tertimpa manusia (bawahannya sendiri). 


\section{Tindak Tutur Ekspresif Menyalahkan}

Terdapat pula tindak tutur ekspresif menyalahkan dalam novel My Stupid Boss 5. Tindak tutur ekspresif dengan indikator menyalahkan ditandai dengan adanya tuturan dari penutur kepada mitra tutur yang bermaksud menyalahkan perbuatan yang telah dilakukan mitra tutur atau pihak yang bersangkutan dengan penutur. Ada beberapa contoh tindak tutur ekspresif dengan indikator mengeluh.

(11) "Ini namanya bukan rebahan! Mana ada orang donor darah sampek tidur ngeringkuk mulut nganga suara ngorok kemana-mana!"

(MSB5:39)

Konteks contoh data (11) adalah tokoh Gue yang menyalahkan tokoh Bossman (atasan) yang tertidur setelah donor darah. Ekspresi marah dengan menyalahkan mitra tutur jelas sekali terlihat pada contoh data di atas. Tindak tutur ekspresif dengan indikator menyalahkan pada contoh data tersebut tidak akan terjadi jika tanpa ada pemicunya. Penutur tokoh Gue menyalahkan mitra tutur (tokoh Bossman) yang dengan seenaknya mengaku rebahan, padahal sudah dilakukan dalam jangka waktu yang lama. Hal tersebut yang memicu kemarahan kemudian muncul ekspresi menyalahkan dari penutur pada contoh data di atas.. Perhatikan kalimat "Ini namanya bukan rebahan! Mana ada orang donor darah sampek tidur ngeringkuk mulut nganga suara ngorok kemana-mana!" Kata rebahan dapat diartikan sebagai berbaring sejenak sekadar untuk beristirahat. Contoh tindak tutur ekspresif di bawah ini juga termasuk tindak tutur dengan indikator menyalahkan.

(12) Gue : Bapak, tasnya dinaikin dong ke compartment. Jangan ditarok di bangku. Bossman : Bentar, dooong! Ini kan banyak bawaannya!

Gue : Enggak usah marah-marah kali, Pak.

Bossman : Bukannya ngebantuin malahan nyuruh aja! Bantuin, dong!

Gue : Ya, awas dong Bapak menghalangi gitu!
Bossman : Makanya jangan makan banyak-banyak! Jadi, enggak muat!

(MSB5:42)

Konteks contoh data (12) percakapan antara Bossman dan tokoh Gue (bawahannya) terjadi di dalam kabin pesawat dan terdapat ekspresi menyalahkan dari setiap ungkapan pada tuturan di atas. Ekspresi saling menyalahkan tersebut antara penutur dan mitra tutur (antara tokoh Bossman dan bawahannya) membuat cerita ini semakin menarik dan jenaka.

Tuturan yang mengandung ungkapan menyalahkan pada contoh data (12), pertama dari tokoh Gue, kedua dari tokoh Bossman, dan selanjutnya bersahut-sahutan dengan saling menyalahkan hingga pada kalimat terakhir. Tindak tutur ekspresif dengan indikator menyalahkan terlihat dengan adanya beberapa ekspresi menyalahkan pada contoh di atas. Kalimat pertama "Bapak, tasnya dinaikin dong ke compartment. Jangan ditarok di bangku" adalah ekspresi menyalahkan tokoh Gue kepada tokoh Bossman yang seenaknya menyimpan tasnya di tempat duduk. Kalimat "Bukannya ngebantuin malahan nyuruh aja! Bantuin, dong!" ini juga ekspresi mengandung indikator menyalahkan, yakni tokoh Bossman yang menyalahkan tokoh Gue yang tidak membantunya menyimpan barang bawaannya. Dibalas juga dengan ekspresi menyalahkan dari tokoh Gue pada kalimat "...awas dong Bapak menghalangi gitu!" yang menyalahkan tokoh Bossman yang menghalangi jalan di dalam pesawat. Kemudian lanjut tokoh Bossman lagi yang menyalahkan tokoh Gue pada kalimat "Makanya jangan makan banyak-banyak! Jadi, enggak muat!"

Contoh lainnya dari tindak tutur ekspresif dengan indikator menyalahkan.

(13) "Adoh! Kamu mestinya bilangin saya ke luar negeri dong! Ke Eropa! Gimana sih kamu!"”

(MSB5:51)

Konteks contoh data (13) adalah penutur (tokoh Bossman) yang 
menyalahkan mitra tutur (tokoh Gue). Ekspresi marah dengan menyalahkan mitra tutur jelas sekali pada contoh data di atas. Dengan demikian, tuturan pada contoh data (13) jelas mengandung tindak tutur ekspresif dengan indikator menyalahkan. Penutur mengeluarkan ekspresi menyalahkan terlihat pada kalimat "...Kamu mestinya bilangin saya ke luar negeri dong! Ke Eropa! Gimana sih kamu!" Tindak tutur ekspresif dengan indikator menyalahkan juga tampak pada contoh data berikut.

(14) Gue : Ya, Bapak juga belum bayar gaji saya.

Bossman : Salah sendiri kenapa minta gaji kegedean!

(MSB5:69)

Konteks yang terdapat pada contoh data (14) adalah penutur (tokoh Bossman) yang menyalahkan mitra tutur (tokoh Gue). Tuturan tokoh Bossman pada kalimat "Salah sendiri kenapa minta gaji kegedean!" terlihat menyalahkan mitra tutur (tokoh Gue) yang sebelumnya menyatakan bahwa tokoh Bossman belum membayar gaji tokoh Gue seperti tuturan pada kalimat "Bapak juga belum bayar gaji saya." Tindak tutur ekspresi dengan indikator menyalahkan yang dilakukan tokoh Bossman tersebut tampak membuat tokoh Gue di dalam cerita ini semakin kesal. Contoh lainnya, seperti pada data berikut.

(15) "Ssss... dia bukan muslim, Pak." (MSB5:83)

Konteks yang terdapat pada contoh data (15) adalah penutur (tokoh Gue) yang menyalahkan mitra tutur (tokoh Bossman). Tuturan menyalahkan dari tokoh Gue pada kalimat "Ssss... dia bukan muslim, Pak" jelas menyalahkan mitra tutur (tokoh Bossman) yang pada tuturan sebelumnya mengucapkan salam seperti halnya kepada muslim. Tindak tutur ekspresi dengan indikator menyalahkan tersebut tampak dilakukan tokoh Gue kepada tokoh Bossman.

\section{Tindak Tutur Ekspresif Memuji}

Tindak tutur ekspresif lain yang ditemukan dalam novel My Stupid Boss 5 adalah tindak tutur ekspresif memuji. Tindak tutur ekspresif dengan indikator memuji ditandai dengan adanya tuturan dari penutur untuk memuji kepada mitra tutur atau pihak lain yang dituju. Contoh tindak tutur ekspresif dengan indikator memuji dapat dilihat pada contoh data berikut.

(16) "Ya, udah, saya panggil Si Samir, deh. Biasanya akal dia ada aja buat benerin mesin mogok."

(MSB5:26)

Konteks contoh data (16) adalah penutur (tokoh Gue) yang memuji tokoh Samir yang pandai dalam hal memperbaiki mesin yang mogok. Pengakuan akan keunggulan sesuatu/seseorang jelas terlihat dalam tuturan contoh data di atas, seperti pada kalimat ..." Biasanya akal dia ada aja buat benerin mesin mogok." Dengan adanya pengakuan keunggulan kepada seseorang tersebut, tuturan pada contoh data (16) jelas mengandung tindak tutur ekspresif dengan indikator memuji. Tindak tutur ekspresif lainnya dengan indikator memuji juga tampak pada contoh data berikut ini.

(17) "Iyah..hah..hah. Saya akui.. Bapak hebat malam ini.. Hebat.."

(MSB5:86)

Konteks contoh data (17) adalah penutur (tokoh Gue) yang memuji tokoh mitra tutur (Bossman) karena memiliki ide yang brilian, tidak seperti biasanya. Ekspresi memuji pada kalimat "Saya akui.. Bapak hebat malam ini.. Hebat.." yang diungkapkan tokoh Gue kepada tokoh Bossman memang jarang sekali terjadi, begitu juga sebaliknya. Tindak tutur ekspresif dengan indikator memuji terlihat pada contoh data (17) karena terdapat pengakuan yang tulus dari penutur akan kehebatan mitra tutur.

\section{Tindak Tutur Ekspresif Menyanjung}

Tindak tutur ekspresif terakhir yang ditemukan dalam novel My Stupid Boss 5 
adalah tindak tutur ekspresif dengan indikator menyanjung. Tindak tutur ekspresif dengan indikator menyanjung ditandai dengan adanya tuturan dari penutur kepada mitra tutur untuk mengungkapkan sesuatu yang bersifat menyanjung untuk membangkitkan rasa senang mitra tutur atau pihak yang dituju. Perhatikan contoh tindak tutur ekspresif dengan indikator menyanjung pada contoh data berikut.

(18) "Enggak perlu dokter buat tau Bapak enggak ada masalah jeroan. Satu, selera makan Bapak masih sangat baik. Artinya, jeroan Bapak baik-baik aja. Bentuk tubuh tidak mengecil. Artinya tidak ada body weight loss."

"Hehehe.. pinter juga kamu ya. Enggak sia-sia saya ajarin kamu selama ini."

(MSB5:26)

Konteks contoh data (18) adalah penutur (tokoh Bossman) yang menyanjung mitra tutur (tokoh Gue) akan kepintarannya dalam menganalisis suatu masalah. Namun, sanjungan pada kalimat “... pinter juga kamu ya..." yang dilontarkan penutur menjadi tidak tulus karena langsung diikuti dengan kalimat "Enggak sia-sia saya ajarin kamu selama ini" artinya penutur tetap arogan dengan memuji dirinya sendiri. Pernyataan kekaguman penutur pada contoh data (18) tetap merupakan tindak tutur ekspresif dengan indikator menyanjung. Perhatikan juga contoh tindak tutur ekspresif lainnya dengan indikator memuji berikut.

(19) "Enggak usah pusing kalo soal kerjaan, Pak. Aman...

"Untung saya punya kamu..."

"Tumben..."

(MSB5:146)

Konteks dari contoh data (19) adalah penutur (tokoh Bossman) yang menyanjung mitra tutur (tokoh Gue) yang telah berhasil menenangkan hatinya dari masalah pekerjaan. Ungkapan penutur pada kalimat "Untung saya punya kamu..." bermakna penutur merasa beruntung memiliki karyawan yang baik kepada mitra tutur.
Kemudian ungkapan tersebut disusul dengan ungkapan dari mitra tutur "Tumben" yang artinya tidak seperti biasanya. Ungkapan yang bertujuan menyenangkan hati mitra tutur yang diucapkan penutur pada contoh data di atas jelas merupakan tindak tutur ekspresif dengan indikator menyanjung.

\section{PENUTUP}

Tindak tutur ilokusi ekspresif yang terdapat dalam tuturan novel My Stupid Boss 5 karya Chaos@Work ada lima (5) indikator: (a) tindak tutur ekspresif mengkritik; Tindak tutur ekspresif dengan indikator mengkritik ditandai dengan adanya tuturan dari penutur yang berupa kecaman atau tanggapan yang disertai dengan uraian dan pertimbangan baik atau buruk terhadap suatu karya, pendapat, tindakan dan sebagainya yang ditujukan kepada mitra tuturnya. (b) tindak tutur ekspresif mengeluh; Tindak tutur ekspresif dengan indikator mengeluh ditandai dengan tuturan yang berisi keluhan penutur kepada mitra tutur atau pihak yang dituju. (c) tindak tutur ekpresif menyalahkan; Tindak tutur ekspresif dengan indikator menyalahkan ditandai dengan adanya tuturan dari penutur kepada mitra tutur yang bermaksud menyalahkan perbuatan yang telah dilakukan mitra tutur atau pihak yang bersangkutan dengan penutur. (d) tindak tutur ekspresif memuji; Tindak tutur ekspresif dengan indikator memuji ditandai dengan adanya tuturan dari penutur untuk memuji kepada mitra tutur atau pihak lain yang dituju. (e) tindak tutur ekspresif menyanjung;

Tindak tutur ekspresif dengan indikator menyanjung ditandai dengan adanya tuturan dari penutur kepada mitra tutur untuk mengungkapkan sesuatu yang bersifat menyanjung untuk membangkitkan rasa senang mitra tutur atau pihak yang dituju. Berbagai ragam ekspresi tersebut bagaimanapun telah membentuk novel ini menjadi menarik untuk dibaca. Keragaman tersebut turut membantu membuat cerita 
menjadi lebih hidup dan dapat dinikmati oleh pembaca.

Bagaimanapun, artikel ini hanyalah salah satu bentuk pembacaan terhadap sebuah karya sastra. Masih memungkinkan

\section{DAFTAR PUSTAKA}

Austin, J. L. (1962). How To Do Things with Words. New York: Oxford University Press.

Blum-Kulka, S. (1989). Cross-Cultural Pragmatics: Request and Apologies. New Jersey: Ablex Publishing Corporation.

Chamalah, E. T. (2016). Tindak Tutur Ekspresif pada Bak Truk sebagai Alternatif Materi Ajar Pragmatik. Bahastra, XXXV, 27-40.

Chaos@Work. (2016). My Stupid Boss 5 (1st ed.). Yogyakarta: Gradien Mediatama.

Defina, N. (2018). Tindak Tutur Ekspresif pada Anak-Anak saat Bermain Bola di Lapangan. Ranah: Jurnal Kajian Bahasa, 7(1), 69. https://doi.org/10.26499/rnh.v7i1.469

Murti, S., Nisai Muslihah, N., \& Permata Sari, I. (2018). Tindak Tutur Ekspresif dalam Film Kehormatan di Balik Kerudung Sutradara Tya Subiakto Satrio. Silampari Bisa: Jurnal Penelitian Pendidikan Bahasa Indonesia, Daerah, Dan Asing, 1(1), 17-32. https://doi.org/10.31540/silamparibis banyak sekali bacaan dan cara pandang yang berbeda. Dalam membaca sebuah karya sastra. Siapa pun pembaca berhak atas makna yang didapatnya atas sebuah karya sastra.

a.v1i1.7

Riswanti. (2014). Analisis Tindak Tutur Direktif dan Ekspresif dalam Novel Kembang Saka Persi. Jurnal Program Studi Pendidikan Bahasa Dan Sastra Jawa, 05(04), 71-77.

Rustono. (1999). Pokok-Pokok Pragmatik. Semarang: CV IKIP Semarang Press.

Searle, J. R. (1971). The Philosophy of Language. New York: Oxford University Press.

Searle, J. R. (1975). Searle, J. R. 1975. Indirect Speech Act. dalam (ed) P. Cole \& J. L. Morgan Syntax and Semantics 3: Speech Act. New York: Academic Press. New York: Academic Press.

Sudaryanto. (1993). Metode dan Aneka Teknik Analisis Bahasa. Yogyakarya: Duta Wacana University Press.

Susmiati, Tutik; Andianto, Mujiman Rus; Husniah, F. (2013). Tindak Tutur Ekspresif Guru terhadap Siswa dalam Pembelajaran Bahasa Indonesia Kelas VIII SMP Negeri 7 Jember. Pancaran, 2(2), 149--160.

Yule, G. (1996). Pragmatik. Yogyakarta: Pustaka Pelajar. 
